\title{
Urological Complications and Management After Gynecological Operations
}

\author{
Jinekolojik Operasyonlar Sonrası Görülen Ürolojik Komplikasyonlar ve Yönetimi \\ ๑ B Bahar Yüksel, ๑ Murat Ekmez*, ๑ Pınar Yalçın Bahat***, ๑ Hazal Atay*, ๑ Cem Dane*, \\ ๑ Ömer Sarılar**, ๑ Faruk Özgör* *
}

Esenler Maternity and Children Health Hospital, Clinic of Obstetrics and Gynecology, Istanbul, Turkey

* University of Health Sciences, Haseki Training and Research Hospital, Clinic of Obstetrics and Gynecology, Istanbul, Turkey

** University of Health Sciences, Haseki Training and Research Hospital, Clinic of Urology, istanbul, Turkey

${ }^{* * * K a n u n i}$ Sultan Süleyman Training and Research Hospital, Clinic of Obstetrics and Gynecology, Istanbul, Turkey

\begin{abstract}
Aim: We aimed to evaluate the urological complications of gynecologic operations in a tertiary academic center and to evaluate the methods of treatment of these complications.

Methods: Files of all patients, who underwent gynecological surgery between January 2016 and January 2019, were retrospectively reviewed from the hospital database. The patients with urological complications included in the study. Pediatric ( $<18$ years old) patients, who underwent emergency surgery, and patients with incomplete medical records were excluded from the study. American Anesthesia Society score, menopausal status, body mass index (BMI), preoperative hemoglobin level, postoperative hemoglobin level, length of hospital stay and number of previous surgeries were recorded. In addition, the patients with urological complications were evaluated in terms of the indications for surgery, type of surgery, type of urological complication and the way of treatment of the complication.
\end{abstract}

Results: After 79 patients were excluded according to exclusion criteria, of the 1754 patients who had undergone a gynecological operation, a total of 21 (1.19\%) patients had urological complications and the bladder was the most common site of injury (61.9\%). The mean age and mean BMI of the patients were 47.8 years and $25.25 \mathrm{~kg} / \mathrm{m}^{2}$, respectively. Urological complications occurred most commonly during staging surgeries due to ovarian or cervix cancer and during laparoscopic or abdominal hysterectomy due to large fibroids. When all operations were evaluated, bladder injury was the most common urological complication.

Conclusion: Our study showed that urological complications during gynecological operations are rare (1.19\%) and the most frequently injured organ is the bladder (61.9\%). In addition, the risk of ureteral and renal injury increases in operations performed with the indication of malignancy and visualization of injuries is critical during operation and complication can be managed with variable techniques intraoperatively.

Keywords: Urologic complications, bladder injury, gynecologic operations

\section{Öz}

Amaç: Çalışmamızda, üçüncü basamak bir merkezde yapılan jinekolojik operasyonların ürolojik komplikasyonlarını ve bunların yönetimini değerlendirmeyi amaçladık.

Yöntemler: Ocak 2016-Ocak 2019 tarihleri arasında üçüncü düzey bir merkezde jinekolojik cerrahi geçirmiş hastaların verileri hastane veri-kayıt sisteminden tarandı. Bunlar içerisinden ürolojik komplikasyon görülen hastalar çalışmaya dahil edildi. Çocuk hastalar (<18 yaşından küçük), acil opere edilen hastalar ve eksik verisi olan hastalar çalışma dışı bırakıldı. Amerikan Anestezi skoru, menopozal durum, vücut kitle indeksi (VKi), preoperatif hemoglobin seviyesi, postoperatif hemoglobin seviyesi, hastanede yatış süresi ve daha önce geçirilen operasyonlar kaydedildi. Demografik özellikler, operatif veriler, görülen ürolojik komplikasyonlar ve bunların yönetimi analiz edildi.

Bulgular: Yetmiş dokuz hasta dışlama kriterlerine göre dışlandıktan sonra jinekolojik ameliyat geçiren 1754 hastanın toplam 21 'inde $(\% 1,19)$ ürolojik komplikasyon olduğu ve en sık yaralanan organın mesane $(\% 61,9)$ olduğu görüldü. Hastaların ortalama yaşı ve VKi ortalamaları sırasıyla 47,8 yıl ve $25,25 \mathrm{~kg} /$ $\mathrm{m}^{2}$ idi. Ürolojik komplikasyonlar en sık over kanseri veya serviks kanserine bağlı evreleme ameliyatları sırasında ve büyük fibroidler nedeniyle laparoskopik veya abdominal histerektomi sırasında meydana gelmişti. Tüm operasyonlar değerlendirildiğinde en sık görülen ürolojik komplikasyon mesane yaralanması idi.

Sonuç: Çalışmamız jinekolojik operasyonlar sırasında ürolojik komplikasyonların nadir olduğunu $(\% 1,19)$ ve en sık yaralanan organın mesane olduğunu göstermiştir $(\% 61,9)$. Ek olarak, malignite nedeni ile yapılan operasyonlarda üreteral ve böbrek hasarı riskinin de arttığı ve operasyon sırasında yaralanmaların saptanmasının kritik öneme sahip olduğu görülmüştür.

Anahtar Sözcükler: Ürolojik komplikasyonlar, mesane yaralanması, jinekolojik ameliyatlar
Address for Correspondence/Yazışma Adresi: Bahar Yüksel, Esenler Maternity and Children Health Hospital, Clinic of Obstetrics and Gynecology, İstanbul, Turkey E-mail: baharyl86@gmail.com ORCID: orcid.org/0000-0003-3728-3414

Received/Geliş Tarihi: 22 October 2019 Accepted/Kabul Tarihi: 07 December 2019
${ }^{0}$ Copyright 2020 by The Medical Bulletin of istanbul Haseki Training and Research Hospital The Medical Bulletin of Haseki published by Galenos Yayinevi. ${ }^{\bullet}$ Telif Hakkı 2020 istanbul Haseki Eğitim ve Araştırma Hastanesi Haseki Tıp Bülteni, Galenos Yayınevi tarafından yayınlanmıştı. 


\section{Introduction}

Female urinary and genital tracts are closely related anatomically and this anatomical relationship makes them vulnerable to injury during surgery. Advances in gynecologic operation techniques and the growing experience of gynecologists decreased the frequency of urological injuries (1). However, the incidence of urinary tract injury associated with pelvic surgery has been reported to be $0.2 \%-1 \%$. The increase in the number of recurrent surgeries performed, and factors encountered during surgery such as adhesions and anatomical variations, prevented decrease in number of complications (2).

Urinary tract injuries can be categorized as urethral injuries, bladder laceration, ureteral injuries or any harm to the kidneys. However, due to the different definition of urinary tract injuries and surgeons' reluctance to mention their complications, the exact rate is unknown (3). This also causes confusion in the determination of treatment methods. Lee et al. (4) performed urethral stenting and end-to-end anastomosis for ureteral injuries, but did not define the patient- or injury-based selection criteria. On the other hand, Pal et al. (5) used primary suturing for bladder injuries and achieved $100 \%$ success rate in their series.

Urinary complications associated with gynecologic surgery have a widely variable incidence and there are various methods for the management of those complications. Thus, in the present study we aimed to analyze urologic complications occurred during gynecologic operations and discuss the management modalities.

\section{Methods}

\section{Study Design}

Patients who underwent gynecologic procedures between January 2016 and January 2019 in a tertiary academic center were analyzed retrospectively. Operations with urologic complications were included in the study. Patients' previous medical records, detailed physical examination findings, age, menopausal status, American Society of Anesthesiologists Classification (ASA) scores and body mass index (BMI) were noted. Also, pre- and post-operative hemoglobin levels, length of hospital stay, indications for gynecologic surgery, site of injury and injury management modality were recorded. Pediatric ( $<18$ years old) patients, who underwent emergency surgery, and patients with incomplete medical records were excluded from the study.

\section{Preoperative Assessment and Complication Management}

All patients were evaluated by experienced anesthesiologists before the surgery and informed consent was obtained from each patient. For every patient with suspected urological complication, urology consultation was performed and management of complication was carried out in cooperation between gynecologists and urologists. A detailed physical examination, urine test, serum creatinine analysis and urinary system ultrasonography were performed 1, 3 and 6 months after discharge.

This study was approved by the Ethics Committee of University of Health Sciences, Haseki Training and Research Hospital (Ethics Committee no: 574, decision no: 2018574).

\section{Statistical Analysis}

The Statistical Package for the Social Sciences for Windows v.23.0 (SPSS Inc., Chicago, IL, USA). The numerical data were expressed as mean ( \pm standard deviation) or median (interquartile range). The categorical variables were expressed as numbers and percentages.

\section{Results}

Records of 1833 patients were reviewed, and 79 patients were excluded from the study due to the exclusion criteria. Out of 1754 patients who underwent gynecological surgery, 21 were found to have urinary complications (1.16\%). The mean age and the mean BMI were 47.8 years and $25.25 \mathrm{k} / \mathrm{m}^{2}$, retrospectively. Nine patients $(42.9 \%)$ were premenopausal. The mean difference between the preoperative and postoperative hemoglobin levels was $1.61 \mathrm{~g} / \mathrm{dL}$. A total of six patients required blood transfusion (28.5\%). Only in one patient who had kidney injury a transient increase in creatinine level was detected and treated with intravenous fluid therapy. Eleven patients had a history of surgery, including hysterectomy, ovarian cystectomy, myomectomy, c-section, cholecystectomy and appendectomy. The mean length of hospital stay was 8.95 days (Table 1).

Indications for gynecologic surgery were variable, including giant myomas in six patients, recurrent surgery in two, abnormal uterine bleeding in four, cervical cancer in two, ovarian cancer or adnexal mass in six and urinary incontinence in one patient. A total of 14 injuries occurred during laparotomy or vaginal surgery and seven injuries, during laparoscopic surgery. All complications occurring during laparoscopic surgery were managed laparoscopically. The bladder was the most commonly injured organ (13 patients, 61.9\%). Ureteral injury was observed in six patients. Renal vein injury and urethral injury were detected in one patient (Table 2).

All the 13 bladder injuries were managed by primary suturing intraoperatively and bladder leak test was done for all patients. Also, one urethral laceration was sutured 
perioperatively, mesh was removed and, a Foley catheter was inserted and left in place for 5 days. In patients with urethral injuries, three patients were managed by suturing and double-J stent insertion and two patients were treated with end-to-end anastomosis and double-J stent placement. Ureteroneocystostomy was done in one patient with distal urethral injury. One patient with renal vein injury underwent nephrectomy (Table 3).

\section{Discussion}

Gynecologists should be aware of frequency, underlying mechanism and management of urological complications occurring during surgery. Although most of urological complications during gynecological operations are not fatal, complications are associated with increased operative time and longer hospital stay, in addition, brings economic burden to health care systems (6). Also, urological complications following gynecological surgery increase the re-admission and re-operation rates (7).

\begin{tabular}{|c|c|}
\hline Patient number & 21 \\
\hline Mean age (years) & $47.8 \pm 21.4$ (range: $23-70)$ \\
\hline $\begin{array}{l}\text { Menopausal status } \\
\text { (non/menopausal) }\end{array}$ & $9 / 12$ \\
\hline Mean BMI patients $\left(\mathrm{kg} / \mathrm{m}^{2}\right)$ & $25.25 \pm 8.12$ (range: $21-31)$ \\
\hline \multicolumn{2}{|l|}{ ASA score } \\
\hline 1 & 9 \\
\hline 2 & 8 \\
\hline 3 & 3 \\
\hline 4 & 1 \\
\hline $\begin{array}{l}\text { Mean preoperative hemoglobin } \\
\text { level }\end{array}$ & 11.49 (range: 6.6-13.8) \\
\hline $\begin{array}{l}\text { Mean postoperative hemoglobin } \\
\text { level }\end{array}$ & 9.88 (range: 8.8-12) \\
\hline Previous surgery history (number) & $11(52.4 \%)$ \\
\hline Gynecologic surgery & 9 \\
\hline C section & 6 \\
\hline Hysterectomy & 2 \\
\hline Ovarian cystectomy & 1 \\
\hline Myomectomy & 1 \\
\hline Non-gynecologic surgery & 2 \\
\hline Cholecystectomy & 1 \\
\hline Appendectomy & 1 \\
\hline $\begin{array}{l}\text { Mean hospitalization duration } \\
\text { (days) }\end{array}$ & 8.95 (range: 2-32) \\
\hline Mean operation duration (minutes) & 177.7 (range: $35-253$ ) \\
\hline Mean blood transfusion rates & $6 / 21(28.5 \%)$ \\
\hline \multicolumn{2}{|l|}{ BMI: Body mass index, ASA: Acetylsalicylic acid } \\
\hline
\end{tabular}

Previous reports demonstrated that the bladder was the most commonly injured organ with an incidence of $0.49 \%$ (8). Risk factors for bladder injury include previous surgery, radiotherapy, malignancies, history of pelvic inflammatory disease and giant adnexal mases or uterine myomas. Method of bladder injury detection is still not clear, Gilmour at al. (1) claimed that bladder injuries were

\begin{tabular}{|c|c|}
\hline Operation indication & Number of cases \\
\hline Giant myomas & 6 \\
\hline Ovarian cancer or adnexal mass & 6 \\
\hline Resistant abnormal uterine & 4 \\
\hline Bleeding & 2 \\
\hline \multicolumn{2}{|l|}{ Recurrent surgery } \\
\hline Cervical cancer & 2 \\
\hline Urinary incontinence & 1 \\
\hline \multicolumn{2}{|l|}{ Type of surgery } \\
\hline \multicolumn{2}{|l|}{ Laparotomic or vaginal } \\
\hline Debulking surgery & 5 \\
\hline Wertheim hysterectomy & 3 \\
\hline Oophorectomy & 2 \\
\hline Type 1 hysterectomy & 1 \\
\hline Myomectomy & 1 \\
\hline Lymphadenectomy & 1 \\
\hline Incontinence surgery & 1 \\
\hline \multicolumn{2}{|l|}{ Laparoscopic } \\
\hline Hysterectomy & 3 \\
\hline Lymphadenectomy & 2 \\
\hline Ovarian cystectomy & 1 \\
\hline Myomectomy & 1 \\
\hline \multicolumn{2}{|l|}{ Injury site } \\
\hline Bladder & 13 \\
\hline Ureter & 6 \\
\hline Kidney & 1 \\
\hline Urethra & 1 \\
\hline
\end{tabular}

Table 3. Type of urinary injuries and repair methods

\begin{tabular}{|l|l|l|}
\hline Type of injury & Repair method & Number of cases \\
\hline Urethra & Primary repair & 1 \\
\hline Bladder & Primary repair & 13 \\
\hline \multirow{2}{*}{ Ureter } & Ureteral stent indwelling & 3 \\
\cline { 2 - 3 } & End-to-end anastomosis & 2 \\
\cline { 2 - 3 } & Ureteroneocystostomy & 1 \\
\hline $\begin{array}{l}\text { Kidney } \\
\text { (renal artery injury) }\end{array}$ & Unilateral nephrectomy & 1 \\
\hline
\end{tabular}


more frequent than those detected by the naked eye so intraoperative cystoscopy should be applied to increase detection rates for almost four times. However, that method requires additional equipment and is associated with longer operative time; also, the authors did not clarify the exact indications for cystoscopy. Many surgeons supported that retrograde injection of methylene blue was effective, reliable and easily replicable option for detection of bladder injury by visualization of any leak from the injured part of the bladder (9). After identification, the main goal should be repairing the injury immediately. In our study 13 injuries out of 21 were bladder injury detected by methylene blue injection and all were repaired perioperatively.

Ureteral injuries are the second most common urinary tract injury experienced in gynecological operations with an increased incidence with the use of electrosurgery modalities in both laparoscopy and laparotomy and due to distortion of the anatomy caused by adhesions in gynecologic malignancies. Ureters are anatomically closely related with ovaries and uterine vessels which is the reason of the majority of urethral injuries. Lee et al. (4) reported that $23.9 \%$ of all urinary tract injuries were urethral injury in their study. The crucial part for avoiding ureteral injuries is visualization of the ureter by observing the peristaltic contractions. Another option is inserting a double-J catheter as a precaution. Delacroix and Winters (9) suggested that the choice for ureteral stenting was a preference of the surgeon. In our practice, we choose using observation of peristaltic movement instead of ureteric catheter insertion. Based on the location, urethral injuries are managed with indwelling stent placement, end-to-end anastomosis and ureteroneocystostomy. In the present study, seven patients experienced ureteral injury, managed by indwelling stent placement in three, end-toend anastomosis in two and by ureteroneocystostomy in two patients.

Urethral injuries are rare in gynecologic surgeries but may occur in vaginal operations in patients with changes in pelvic anatomy due to previous operations, difficult vaginal birth and previous radiotherapy. In their study, Taweel and Rabah (10) found no risk of bladder or urethral injury in patients undergoing transobturator tape procedure due to female stress urinary incontinence. In their study including 241 women who underwent transobturator tension-free vaginal tape procedure, Abdel-Fattah et al. (11) reported that the rate of bladder injury and urethral injury was $0.5 \%$. When detected during surgery, primary repair should be the method of choice. In our study, one patient with a distorted vaginal anatomy related to a difficult vaginal delivery had a urethral injury during transobturator tape insertion and underwent an immediate repair.
Kidney injury during gynecologic surgeries is a rare occurrence because the kidneys are located in the upper retroperitoneal region of the abdomen. However, extended surgeries for staging gynecologic malignancies or uterine myomas and endometriosis may require resections in regions close to the renal arteries. In our study, one case with stage 3 ovarian carcinoma had unilateral renal artery injury during paraaortic lymphadenectomy.

\section{Study Limitations}

The present study has some limitations. First, the study had a retrospective nature. Also, it was conducted at a single tertiary academic center and included only onecenter experience. Additionally, surgeries were performed by several surgeons with different experience which may influence complication rates. Lastly, the present study focused on only intraoperative injuries and short-term results and did not investigate long-term outcomes of urological complications occurring during gynecological operations.

\section{Conclusion}

Urological complications associated with gynecological surgery are rare and the bladder is the most common injured organ. Additionally, visualization of injuries is critical during operation and complications can be managed with variable techniques intraoperatively. The results of the present study must be supported by further prospective large-scale studies with longer follow-up durations.

\section{Authorship Contributions}

Concept: B.Y. Design: B.Y., F.Ö. Data Collection or Processing: H.A., M.E., C.D. Analysis or Interpretation: F.Ö., Ö.S. Literature Search: B.Y., P.Y.B. Writing: B.Y.

Conflict of Interest: No conflict of interest was declared by the authors.

Financial Disclosure: The authors declared that this study received no financial support.

\section{References}

1. Gilmour DT, Dwyer PL, Carey MP. Lower urinary tract injury during gynecologic surgery and its detection by intraoperative cystoscopy. Obstet Gynecol 1999;94(5 pt 2):883-9.

2. Ozdemir E, Ozturk U, Celen S, et al. Urinary complications of gynecologic surgery: iatrogenic urinary tract system injuries in obstetrics and gynecology operations. Clin Exp Obstet Gynecol 2011;38:217-20.

3. Likic IS, Kadija S, Ladjevic NG, et al. Analysis of urologic complications after radical hysterectomy. Am J Obstet Gynecol 2008;199:644.e1-3.

4. Lee JS, Choe JH, Lee HS, Seo JT. Urologic complications following obstetric and gynecologic surgery. Korean J Urol 2012;53:795-9. 
5. Pal DK, Wats $V$, Ghosh B. Urologic complications following obstetrics and gynecological surgery: Our experience in a tertiary care hospital. Urol Ann 2016;8:26-30.

6. Slack A, Child T, Lindsey I, et al. Urological and colorectal complications following surgery for rectovaginal endometriosis. BJOG 2007;114:1278-82.

7. Ostrzenski A, Radolinski B, Ostrzenska KM. A review of laparoscopic ureteral injury in pelvic surgery. Obstet Gynecol Surv 2003;58:794-9.

8. Selzman AA, Spirnak JP. Iatrogenic ureteral injuries: a 20-year experience in treating 165 injuries. J Urol 1996;155:878-81.
9. Delacroix SE, Winters JC. Urinary tract injures recognition and management. Clin Colon Rectal Surg 2010;23:104-12.

10. Taweel WA, Rabah DM. Trans obturator tape for female stress incontinence: follow-up after 24 months. Can Urol Assoc J 2010;4:33-6.

11. Abdel-Fattah M, Ramsay I, Pringle S. Lower urinary tract injuries after trans obturator tape insertion by different routes: a large retrospective study. BJOG 2006;113:1377-81. 